\title{
Senior undergraduate students developing and envisioning possible selves after graduation
}

Hien Khong, B. C. Lohman, Nolan Foth, and Eleanor C. Sayre

Department of Physics, Kansas State University, Manhattan, KS 66502

This study is situated within possible selves theory to explore how senior undergraduate students in STEM develop and envision their future possible selves after graduation. We interviewed students at an urban institution in the US and encouraged them to think about who they will be in the future associated with their future career choices. This study presents two case studies: Ricky and Francisco. These two students discuss a variety of academic contexts through which they negotiate and explore career-related possible selves: conferences, experiences from classes and research, maintained aspirations for science, and dissatisfaction with education from high school. However, we found that in some cases, academic contexts alone are not enough to help students develop future possible selves. Rather, they intersect with social contexts (social identity, out-of-school experiences) through which possible selves emerge. Our findings suggest that students might need more than just classroom-based lessons to explore their possible selves. Implications from this research can benefit the ongoing curriculum development aiming at increasing students' interests in STEM-related careers and building a meaningful professional life after graduation. 


\section{INTRODUCTION}

The last few years of an undergraduate degree can be a time of intense introspection and planning for the future as students imagine their professional life after graduation. In physics, they must navigate potentially conflicting expectations from the people around them: earning money, going to grad school, relocating, choosing a career, etc. While career development is a process involving many influential experiences occurring over the lifespan of individuals [1-3], this stage is often accompanied by intense introspection.

On a population level, factors influencing students' career development have been widely examined in science education. School factors (collaborative learning, hands-on research experiences, mentorships, etc.) [4-11] and out-ofschool experiences (family discussion, hiking, fishing, visiting museums, etc.) [12-14] have been found to increase interests in science and over time predict the likelihood to choose a STEM-related career. Social identity (i.e., race, gender, socioeconomic status) also cannot be ignored in career planning $[1,4,11,15]$. Numerous studies examine the effect of social identity on students' career choices such as gender differences in choosing engineering [12, 16, 17], interests and persistence in science careers from marginalized groups [1820]. These factors interact with each other to affect undergraduate students' career exploration in complicated ways.

In this paper, we take up two case studies of senior double STEM majors to understand the contributing factors in their career development, how they envision who they will be, and what they imagine their day-to-day professional life after graduation. We argue that a positive or negative imagination of the future can also impact what students commit to doing or avoiding.

\section{THEORETICAL FRAMEWORK}

To understand their imaginings of the future, we take up possible selves theory. Possible selves are conceptions of "how individuals think about their potential and about their future" including what they would like to become, could become, and are afraid of becoming [21]. Possible selves impact how people behave to attain their goals or avoid their fears, and serve as an essential link between their current state and desired future state. An individual can have multiple possible selves. This paper focuses on career-related possible selves.

The development of possible selves is negotiated with one's past experiences. For example, a past self as a good student with high performance in class might affect that individual to have a school-related self in the future. In contrast, individuals with low achievement in class may not imagine a possible self in academia.

Social identity also contributes to informing possible selves [22, 23]. For example, young people from middleclass contexts tend to develop positive possible selves where they expect to have prestigious careers [24]. In contrast, students from minoritized communities may be associated with low achievement in school, raising the possibility that positive possible academic selves conflict with their social identities [24, 25]. Young women may consider science possible selves not to be a good fit for them [26] because of extensive systemic sexism in science, contributing to a gap between female and male students in generating science-related possible selves [23]. Students' career-based possible selves are connected in an intersectional way to their non-career-based possible selves and the contexts in which they grow up. Many people develop career-based possible selves that are congruent with their social identities and experiences.

Based on different perspectives on possible selves and career development $[4,23,25]$, we explore two main overlapping contexts where students connect their past experiences to construct their possible selves: academic and social contexts. Academic contexts include activities, interactions with peers, professors for educational purposes and supporting students to grow in a scientific discipline. Social contexts include experiences related to out-of-school activities or social identity. These two contexts often blend into each other in some experiences. For instance, if a group of students go to a park to discuss a homework problem, the activity is out-of-school but still for an educational purpose. In this paper, we examine the interaction between these contexts in how they affect students' possible selves.

This study examines two students to compare the academic and social experiences that contribute to their possible selves explorations with contrasting social identities but from the same institution. We answer two research questions: (i) What are academic and social contexts through which students explore their possible selves?, (ii) To what extent do academic contexts intersect with social contexts through which possible selves emerge? We found that conferences, experiences from classes and research, aspirations for science, and dissatisfaction with education are academic contexts that help students construct possible selves. However, in some cases academic contexts alone are not enough to help students develop careerrelated possible selves. Rather, they intersect with social contexts (social identity, out-of-school experiences) through which possible selves emerge.

\section{METHODOLOGY}

Two interviewers conducted 45-minute interviews over Zoom with 19 participants (6 alumni, 13 current students) from an urban institution in the US; the interviewers were unaffiliated with the students' institution. The interview protocol focused on five sections: background, career planning, factors that influence, sense of purpose, and institutional support and resources. For this paper, we focus on narratives relating to students' career interests and imaginations of who they'll be in the future.

Among participants, we were interested in examining se- 
niors as they are transitioning from being students to professionals. This transition requires them to reflect on their life seriously to make decisions. Among seniors we have examined, Francisco (Latino, he/him, physics and math double major) and Ricky (white, he/him, physics and math/computer science double major) stood out as appealing case studies. While other seniors are still debating back-and-forth among options about their future selves, leaving us little data to characterize their possible selves, Ricky and Francisco both have clear senses of who they will be in the future. Additionally, they embody a wide range of their own experiences from both academic and social contexts, and the way these contexts influence their career explorations is quite different. Examining the development of their future selves provides an illuminating comparison and contrast.

The analysis began by focusing on students' responses to two sections in the interview protocol: career planning, and factors that influence. Some questions we asked were: What are you planning to do next after graduation?, How has your thinking about careers changed over time?, Are there particular experiences that stood out to you as helping you change your perspective?. We then read through the narratives and marked instances that gave us a clue for possible selves development. Next, we examined and classified whether those instances are experiences brought from an academic or a social context (see Section II). The analysis process was repeatedly discussed among three researchers to ensure all experiences that influenced the development of possible selves were analyzed and classified. We hypothesize that the development of possible selves can be developed (i) solely within academic contexts, e.g., "I have done very well in all physics courses, so becoming a physicist is the best for me."; or (ii) within an overlap between both academic and social contexts, e.g., "Being a woman in physics classes is challenging, becoming a physicist is not for me." We examine Ricky and Francisco to test these hypotheses in following sections.

\section{RICKY'S FUTURE POSSIBLE SELVES}

Ricky (white, he/him) is a senior double majoring in physics and math/computer science. Thinking about his future, Ricky envisioned a $\mathrm{PhD}$ program where he could "[take his] physics knowledge and [apply] it to medicine", so that he "could be a physicist but then also be like a board-certified doctor." We found that the intersection of academic contexts (conferences, research) and social contexts (personal health care, medical dramas) results in a possible self in medical physics (see Fig. 1).

Conferences helped Ricky begin the journey of pursuing medical physics. As a junior, "[he] was at Phys Con and the SACNAS conference, and [he] met a bunch of medical physicists, and [he] learned about this new branch, that is medical physics." After conferences, he "[has] interacted with, emailed, and been on Zoom calls" with a speaker who has become Ricky's mentor. Now as a senior, his perception of the

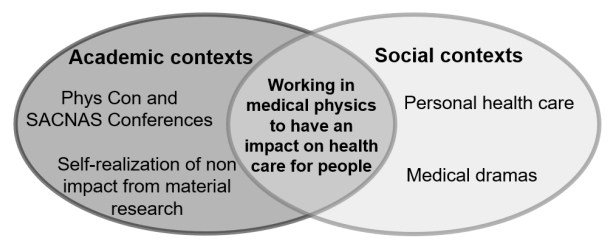

FIG. 1: Ricky's possible self development. The mutual area represents the possible self emerging from the overlap between academic and social contexts.

field is much more developed. Ricky described his possible self as "doing research and working in a clinical aspect, if you take your career that way and can actually become board certified." We argue that Ricky is able to envision his future possible self because of the conferences that he has attended and conversations with professional medical physicists. Ricky recognizes this impact: "What has been most impactful to my trajectory, is going to the conferences." Through Ricky's discourses, we conclude conferences are academic contexts that allowed Ricky to develop his possible self.

Research experiences are another academic context through which Ricky ruled out material science and let medical physics come in. Ricky "[has] had two undergraduate research experiences and they were all in material science." He found his research "interesting," "vital and important." However, the experiences did not give him a sense of direct impact on people, resulting in a shift to medical physics where impact is more visualized: "Those fields are obviously great and interesting, but I wanted my work to have more of a direct impact... like I affected a person's life in a really intimate and direct, personal way and that's where medicine came in." Although Ricky didn't end up pursuing material science as a possible self, research gave Ricky an opportunity to "try different things to see, what sticks, what you like and what you don't like." Thus, we claim that research is an academic context that contributes to helping Ricky develop his possible self in medical physics by eliminating material science as a path.

Besides academic contexts, out-of-school experiences play a big role in developing Ricky's possible self. A lifelong interest in healthcare is influenced by his father who "would take [him] through this health store, protein, smoothie shop a block away from [his] house, [they]'d go there after school and get wheatgrass shots, it was one of those life defining moments." At first, "it was just like a habit to do healthy things." Over time, taking care of his health "became a part of [his] personality." He integrated health care into his thinking of a future career, leading to a realization that "wait, there's a whole field of physics where you can take those interests and improve health care for many people." "All of that coming together was like perfect" to work in medical physics.

Another out-of-school experience is when Ricky "[watches] medical dramas on TV." He recalled: "I don't want to be involved in emergency medicine, but then I realized, wait, there's other ways to be involved in medicine...being in the medical world, clinical side 
of things, is something that I'm actually interested in." From these excerpts, we conclude that his out-of-school experiences (personal health care, medical dramas) are social contexts through which Ricky developed his possible self.

Overall, academic contexts (conferences, research) intersect with out-of-school experiences (personal health care, medical dramas) to help Ricky realize his interest in medical physics and move away from his research experiences in materials science. To him, medical physics is "the intersection of so many things" which enables him to integrate a lifelong interest in healthcare into his academic interest in physics.

\section{FRANCISCO'S FUTURE POSSIBLE SELVES}

Francisco (Latino, he/him) is a senior student double majoring in math and physics. Francisco wants to do grad school in applied math and become a mathematician. However, when being asked what happens next after grad school, Francisco "knows for sure that [he] wants to be an educator" where he can help youth approach science better. Two possible selves-a mathematician who focuses on research in math and an educator who focuses on improving educationare developed by different motivations and contexts. Fig. 2 and Fig. 3 show the differences in developing these two possible selves.

\section{A. A possible self as a mathematician}

Francisco "would like to become a mathematician" and do research in partial differential equations (PDEs). This possible self first comes from his passion for PDEs, about which he waxed poetic during the interview. When discussing grad programs, he reports: "I had to make sure and double sure that they're doing research in PDEs, otherwise I don't think I'm going to be happy there." His passion for math has remained over time from high school to college and will continue in the future grad school as he recalls: "I knew I always wanted to pursue math." A choice in applied math also makes Francisco's physics studies fulfilling. Francisco envisions his possible self as having "two advisors, one in the math department and then one, in physics or engineering." Pursuing applied math isn't "like discontinuing physics," and "that sort of sealed the deal" for which programs to apply for. Maintaining his aspiration for STEM over time, especially for math, plays a huge role in developing a possible self for Francisco.

What has happened in classes and research also helps Francisco to explore his possible self. Perceiving himself as having "a lot of experiences" through classes and research helps Francisco affirm his choice in applied math. Before graduating, he did three summers of research. The first two were in physics where he looked into the two point correlation function and Type 1a supernova. The third was originally research in applied math; however, the pandemic disturbed that plan and he ended up doing pure math research instead. Regard-

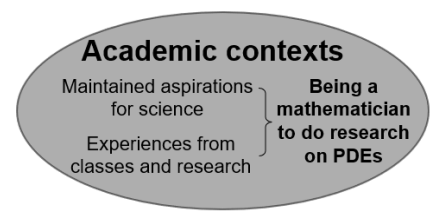

FIG. 2: Francisco' possible self as a mathematician developed within only academic contexts.

less of research in pure or applied math, "[he] felt like any research in math is useful... that [he] might have an idea of sort of what to expect when [he's] doing research in math." His plans to solve PDEs in graduate school are supported by his confidence in his past experience in solving ODEs and PDEs; he has "a lot of experience with that."

Notably, Francisco doesn't talk about social contexts in discussing this possible self, despite interview questions prompting him to talk about family, location, community, and jobs. His possible self as a mathematician is developed only within academic contexts by Francisco's maintained aspirations for the field and experiences of solving math through classes and research.

\section{B. A possible self as an educator to improve science education}

Francisco reports that, growing up, he didn't have much information about science and college. This lack contributes to his possible self as an educator. Francisco repeated the fact that he did not know how college works many times, indicating this as a reason why he wants to improve education for youth: "In high school at least, I felt lost, I didn't know a whole lot of what you could do with math until probably my junior or sophomore year." Moreover, finances were so challenging that Francisco almost gave up on college: "For a long time I didn't know a lot of schools give financial aid. I didn't even know the grant was a thing until the end of my junior year. So for a long time, money was like the biggest thing that just made me think I am not going to go to college or anything."

Francisco also felt he "didn't learn enough science in high school so maybe introducing science at a younger age" is important. He links a lack of science education with his social identity: "My town is like $80 \%$ Mexican and the other $20 \%$ is Hispanic. Most of us don't have that much background in sci-

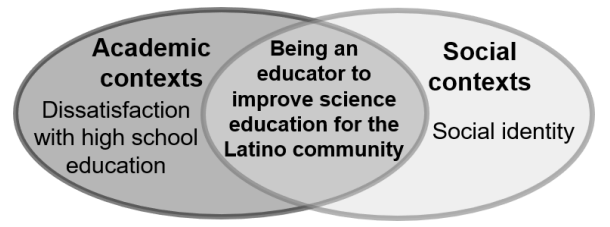

FIG. 3: Francisco's possible self as an educator emerged from the overlap between academic and social contexts. 
ence. A lot of us didn't even know the difference between a chemist and a physicist just because there wasn't really much distinction between scientists." Inadequate exposure to science is what "[he] felt like [he] missed out on in education" and "[he] wants to correct" for young people. When asked about his purpose in life, he said: "Education is probably, education of youth, is also something I'm really concerned about" and "provide the next generation with better scientific education that I felt like I missed out on because I came from where I am, I felt like I owe it to somebody." From these discourses, we conclude that social identity is reflected in dissatisfaction with education, motivating Francisco to become an educator to do something better for his community.

We asked Francisco about his disparate plans for youth education and becoming a PDE researcher. They seemed different to us, and his demeanor and prosody changed when describing them. To him, these two possible selves are poorly connected. He's not sure how he can dedicate his life to both.

\section{DISCUSSION}

This study explores the process of building future possible selves in the light of academic and social contexts. Our students' possible selves are constructed from their past experiences. These experiences can be established from any age and can affect career exploration [1,2]. For example, Ricky brought up a childhood experience of going to a smoothie shop which he called "one of those life defining moments" that inspired him to start taking care of his health. Findings from Ricky's case are also consistent with prior work that found strong relationships between out-of-school experiences and an increase in science interest $[12,13]$. In the light of possible selves theory, not only can out-of-school experiences foster interests in science, they can also have an impact on possible self development where students link their experiences with who they will be in the future. Ricky, for instance, connects his health care obsession to an impact on people's health in his future career.

We found a variety of academic contexts through which students explore their possible selves. Literature suggests research is a great opportunity that attracts students to science careers [5-8]. Our finding partly agrees with this claim because research acts on Ricky and Francisco in different ways. Contrasting with Francisco who does it to fulfill his passion for PDEs, Ricky doesn't find material science research to be his lifelong passion, resulting in a shift towards medical physics. Regardless of students' ultimate choices, research importantly serves as a means to either confirm their passion or help eliminate unwanted paths. Our findings strongly suggest students should engage in research as it can provide positive experiences to impact their possible self development.

Other academic contexts such as Francisco's aspirations for science are aligned with literature [16, 17, 23, 27], suggesting that interest is one of the important components predicting persistence in a discipline. Similarly, Ricky's interest grew from a mentorship found at a conference, agreeing with previous studies that mentorship is critical to the development of careers plans $[5,26]$. Having students attend conferences, workshops, or intensive programs [28] where they have opportunities to hear experts or experienced alumni is highly recommended to help students develop their possible selves.

Social identity is important in possible selves constructions [21, 23, 25, 29], but it plays out very differently for Ricky and Francisco. While both of them talk about helping people in the future, Francisco connects his need to give back to his community and Ricky's scope is depersonalized. Francisco echoes a concern for a gap in lived academic experiences for minority students with limited learning and social resources [30], which can discourage them from envisioning some possible selves. The relationships between possible selves and social identity imply that future-oriented activities to support career development should be contextually and strategically designed for different groups of students so that they can match up with their needs and backgrounds.

Ricky envisions his life working in medical physics. This possible self is constructed by the intersection of academic contexts (conferences, research experiences) and social contexts (personal health care, medical dramas). Francisco imagines his possible self as a mathematician solving PDEs and as an educator improving science education for youth. While a "mathematician" possible self is developed within only academic contexts (aspirations for math, experiences from classes and research), social identity appears in the development of the "educator" possible self. Our findings indicate that future possible selves can be developed by either solely academic experiences or the intersection of academic and social experiences. Supporting students in developing their career planning requires more future-oriented activities that not only help students reflect on their academic experiences but also who they are as persons to people around them. While contributing to the understanding of students' career development, this paper only examines two students, and does not include students whose possible selves are unclear. Future work will continue exploring more case studies to determine more academic and social contexts, especially students whose future possible selves are undeveloped to provide a contrasting picture of the career development among students.

\section{ACKNOWLEDGMENTS}

We are indebted to our research participants and research team. Dr. Kustusch recruited students, provided institutional context, and collaboratively developed the interview protocol. E. A. Beard transcribed the interviews; C. Hass and S. El-Adawy were on our interviewer team. This project was partially funded by the Department of Physics at Kansas State University, Scholarship of Teaching and Learning Grant from DePaul University's Center for Teaching and Learning, and through NSF DUE-1726479/1726113. 
[1] P. J. Hartung, E. J. Porfeli, and F. W. Vondracek, Child vocational development: A review and reconsideration, Journal of vocational behavior 66, 385 (2005).

[2] M. Watson and M. McMahon, Children's career development: A research review from a learning perspective, Journal of Vocational Behavior 67, 119 (2005).

[3] A. Hirschi, S. G. Niles, and P. Akos, Engagement in adolescent career preparation: Social support, personality and the development of choice decidedness and congruence, Journal of adolescence 34, 173 (2011).

[4] C. van Tuijl and J. H. W. van der Molen, Study choice and career development in stem fields: an overview and integration of the research, International journal of technology and design education 26, 159 (2016).

[5] M. Estrada, P. R. Hernandez, and P. W. Schultz, A longitudinal study of how quality mentorship and research experience integrate underrepresented minorities into stem careers, CBE-Life Sciences Education 17, ar9 (2018).

[6] A.-B. Hunter, S. L. Laursen, and E. Seymour, Becoming a scientist: The role of undergraduate research in students' cognitive, personal, and professional development, Science education 91, 36 (2007).

[7] D. Lopatto, Survey of undergraduate research experiences (sure): First findings, Cell biology education 3, 270 (2004).

[8] E. Odera, A. J. Lamm, L. C. Odera, M. Duryea, and J. Davis, Understanding how research experiences foster undergraduate research skill development and influence stem career choice, NACTA Journal 59, 180 (2015).

[9] B. C. Gamse, A. Martinez, and L. Bozzi, Calling stem experts: how can experts contribute to students' increased stem engagement?, International Journal of Science Education, Part B 7, 31 (2017).

[10] J. Osborne, S. Simon, and S. Collins, Attitudes towards science: A review of the literature and its implications, International journal of science education 25, 1049 (2003).

[11] W.-C. Mau and L. H. Bikos, Educational and vocational aspirations of minority and female students: A longitudinal study, Journal of Counseling \& Development 78, 186 (2000).

[12] A. Godwin, G. Sonnert, and P. M. Sadler, Disciplinary differences in out-of-school high school science experiences and influence on students' engineering choices, Journal of Pre-College Engineering Education Research (J-PEER) 6, 2 (2016).

[13] N. R. Council et al., Learning science in informal environments: People, places, and pursuits (National Academies Press, 2009).

[14] N. R. Council et al., Identifying and supporting productive STEM programs in out-of-school settings (National Academies Press, 2015).

[15] J. E. Stets and P. J. Burke, Identity theory and social identity theory, Social psychology quarterly, 224 (2000).
[16] Z. Hazari, G. Sonnert, P. M. Sadler, and M.-C. Shanahan, Connecting high school physics experiences, outcome expectations, physics identity, and physics career choice: A gender study, Journal of research in science teaching 47, 978 (2010).

[17] R. M. Lock, Z. Hazari, and G. Potvin, Physics career intentions: The effect of physics identity, math identity, and gender, in AIP Conference Proceedings, Vol. 1513 (American Institute of Physics, 2013) pp. 262-265.

[18] S. J. Basu and A. C. Barton, Developing a sustained interest in science among urban minority youth, Journal of Research in Science Teaching: The Official Journal of the National Association for Research in Science Teaching 44, 466 (2007).

[19] J. E. Pizzolato, Achieving college student possible selves: Navigating the space between commitment and achievement of long-term identity goals., Cultural Diversity and Ethnic Minority Psychology 12, 57 (2006).

[20] C. M. Yowell, Dreams of the future: The pursuit of education and career possible selves among ninth grade latino youth, Applied developmental science 6, 62 (2002).

[21] H. Markus and P. Nurius, Possible selves., American psychologist 41, 954 (1986).

[22] D. Oyserman and L. James, Possible identities, Handbook of identity theory and research , 117 (2011).

[23] D. Verdín, A. Godwin, G. Sonnert, and P. M. Sadler, Understanding how first-generation college students' out-of-school experiences, physics and stem identities relate to engineering possible selves and certainty of career path, in 2018 IEEE Frontiers in Education Conference (FIE) (IEEE, 2018) pp. 1-8.

[24] S. Weinger, Opportunities for career success: Views of poor and middle-class children, Children and Youth Services Review 22, 13 (2000).

[25] D. Oyserman, D. Bybee, and K. Terry, Possible selves and academic outcomes: How and when possible selves impel action., Journal of personality and social psychology 91, 188 (2006).

[26] B. W.-L. Packard and D. Nguyen, Science career-related possible selves of adolescent girls: A longitudinal study, Journal of career development 29, 251 (2003).

[27] A. Godwin, G. Potvin, Z. Hazari, and R. Lock, Identity, critical agency, and engineering: An affective model for predicting engineering as a career choice, Journal of Engineering Education 105, 312 (2016).

[28] D. Bennett and S. A. Male, An australian study of possible selves perceived by undergraduate engineering students, European Journal of Engineering Education 42, 603 (2017).

[29] M. Rossiter, Possible selves: An adult education perspective, New directions for adult and continuing education 2007, 5 (2007).

[30] J. Banks, K. Au, A. Ball, P. Bell, E. Gordon, K. D. Gutiérrez, S. Brice-Heath, C. Lee, J. Mahiri, N. Nasir, G. Valdes, and $\mathrm{M}$. Zhou, Learning in and out of school in diverse environments: Life-long, life-wide, life-deep (2007). 